\title{
Suitable Planting Density for Chaiya Rice using Parachute Planting Method
}

\section{Waranthon RATTANADET and Suchart CHOENGTHONG*}

Department of Agricultural Science and Technology, Faculty of Science and Industrial Technology, Prince of Songkla University, Suratthani Campus, Suratthani 84100, Thailand

('Corresponding author's e-mail: suchart.c@psu.ac.th)

Received: 15 April 2016, Revised: 20 March 2018, Accepted: 24 April 2018

\begin{abstract}
The effect of planting density on growth and grain yield of Chaiya rice using parachute planting was examined at Pathum Thani Rice Research Center, from September 2014 to January 2015. The particular objective was to examine the suitable planting density when parachute planting was applied. Five densities of Chaiya rice seedlings were thrown similar to parachuting. Those densities were 22,400, $30,720,38,400,48,000$ and 56,320 clumps per rai ( 1 rai $=0.16$ ha). Pre-heading growth varied greatly among densities; this variation was partly related to the number of tillers, lower densities having more tillers per clump than higher densities, respectively. The relationship between tiller number and plant height was not similar. The heights of rice at densities of 22,400, 30,720, 38,400, 48,000 clumps per rai were not significantly different within the group but these were significantly different with the planting density of 56,320 clumps per rai.

Low densities promote head development as the number of heads per clump was higher than those of high densities in most densities. No significant effect of density on filled-grain and unfilled-grain per head. Seed weight per clump showed significant difference between densities except between those of 38,400 and 48,000 clumps per rai. Grain yield varied among densities. Chaiya rice with 22,400 clumps per rai had the highest yield at $786.38 \mathrm{~kg}$ per rai. However, it was not significantly different from yields of rice at densities of 30,720 and 38,400, clumps per rai. However, the grain yield of rice planted at 48,000 and 56,320 clumps per rai was significantly lower than that of 22,400 clumps per rai. It is concluded that there was a consistent effect of plant density on growth and yield of Chaiya rice using parachute planting.
\end{abstract}

Keywords: Chaiya rice, parachute planting method, density, growth, grain yield

\section{Introduction}

Chaiya rice is a fragrant rice commonly grown in Chaiya district, Surat Thani province. This rice has many advantages, such as high grain quality and pleasant aroma when cooked. Generally, rice is planted using the broadcasting method with $9.57 \mathrm{~kg} \mathrm{seed} / \mathrm{rai}$ ( $1 \mathrm{rai}=0.16 \mathrm{ha})$ [1]. The rapid decline in Chaiya rice planting is due to the high cost of production. It is recognized that any further increase in more planting area of the crop may be necessary to use a new planting method. One way of doing this would be to use parachuting planting so that the seedling cost is decreased. It is not known; however, to what extent plant density affects growth and grain yield in Chaiya rice. Hashemi rice grown in Iran using a spacing of $20 \times 20 \mathrm{~cm}^{2}$ provided the highest grain yield of $3415 \mathrm{~kg} /$ ha whereas the lowest grain yield was obtained from the spacing of $15 \times 185 \mathrm{~cm}^{2}$ with $3242 \mathrm{~kg} / \mathrm{ha}$ [2]. The objective of the work reported here was to find a suitable planting density for Chaiya rice using the parachute planting method. 
http://wjst.wu.ac.th

\section{Materials and methods}

The experiment was conducted during September 2014 to January 2015 at Pathum Thani Rice Research Center (latitude $14^{\circ} 01^{\prime} \mathrm{N}$, longitude $100^{\circ} 41^{\prime} \mathrm{E}$ ) in Pathum Thani province in central Thailand. A completely randomized design (CRD) with 4 replications was used. Five treatments were planting densities at 14, 19, 24, 30 and 35 plants $\mathrm{m}^{-2}$. Each plot occupied a $2.5 \mathrm{~m}^{2}$ area.

Seedling trays were used to sow the seed on $5^{\text {th }}$ September 2014 . Irrigation was applied immediately after sowing and irrigation was applied every day to ensure good establishment. Before transplanting, the plots were cultivated for one month. Soil was prepared using hand labor. One day before parachuting, the plots were flooded with water to a depth of $5 \mathrm{~cm}$ and allowed to dry gradually within $12 \mathrm{~h}$. Parachuting was conducted using seedling at the age of 15 days after sowing. The designated rice densities of 22,400, $30,720,38,400,48,000$ and 56,320 clumps per rai were thrown in designed plots to let the roots penetrate into the wet soil. Irrigation was applied immediately after parachuting and the water level was maintained at between 5 and $10 \mathrm{~cm}$. Mixed fertilizers were applied at 7 and 52 days after parachuting to provide $8 \mathrm{~kg}$

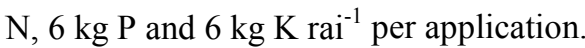

Tiller numbers were counted at 45 and 60 days after parachuting. Ten plants from each plot were sampled and tagged for counting. Plant height was measured when harvesting on the same plants used for tiller number counting. The harvest was conducted at maturity. The number of heads per clump was counted from 5 plants in each plot. At maturity, all heads were threshed, and filled and unfilled-grains per panicle were determined. Seed moisture content and seed weight per clump were measured. The grain yield of each plot was weighed and calibrated at $14 \%$ moisture content.

Statistical analysis was done by using the SPSS software package. Analysis of Variance (Anova.) and Duncan's New Multiple Range Test (DNMRT) were performed to compare the differences of means between treatments.

\section{Results and discussion}

Tiller production was affected by density and there was significantly different between treatments (Table 1). At 45 days after parachuting, tiller number was not significantly different between the 38,400 clumps/rai and the 48,000 clumps/rai, but the difference became greater at later measurement. At 60 days after parachuting, the number of tillers per clump varied from 29.38 to 17.18 tillers/clump. The 22,400 clumps/rai density had the largest tiller number per clump and was significantly different from all other treatments. Similarly, the 30,720 clumps/rai showed significant difference from 38,400, 48,000 and 56,320 clumps/rai in tiller number per clump. However, at both 45 and 60 days after parachuting there was no significant difference in tiller number per clump between 48,000 and 56,320 planting densities. A larger number of tillers was produced at the low density than the high density, because of the ability of the low density to intercept more light than the higher one [3]. Tiller numbers of 5 rice cultivars decreased with increasing density [4].

Plant height at maturity was significantly shorter in the 56,320 clumps/rai than in other densities (Table 1). There was no significant difference in plant height among those planted at 22,400, 30,720, 38,400 and 48,000 clumps/rai. The height of these 4 treatments varied slightly from 140.63 to $142.23 \mathrm{~cm}$; whereas, the height of the 56,320 clumps/rai was $137.32 \mathrm{~cm}$. The 56,320 clumps/rai density may be too dense for plant growth as compared to other treatments. Moreover, when there was higher density, fertilizer was divided giving a lower quantity per clump resulting in insufficient nutrient supply for plant growth. 
http://wjst.wu.ac.th

Table 1 Number of tillers/clump and plant height.

\begin{tabular}{|c|c|c|c|}
\hline \multirow{2}{*}{ Treatment } & \multicolumn{2}{|c|}{ Number of tillers /clump (Mean \pm S.D.) } & \multirow{2}{*}{$\begin{array}{c}\text { Height }(\mathrm{cm}) \\
(\text { Mean } \pm \text { S.D. })\end{array}$} \\
\hline & 45 days & 60 days & \\
\hline 1. 22,400 clumps/rai & $16.23^{\mathrm{a}} \pm 2.750$ & $29.38^{\mathrm{a}} \pm 3.834$ & $142.23^{\mathrm{a}} \pm 6.616$ \\
\hline 2. $30,720 \mathrm{clumps} / \mathrm{rai}$ & $14.40^{b} \pm 3.808$ & $25.33^{b} \pm 6.014$ & $141.23^{\mathrm{a}} \pm 7.659$ \\
\hline 3. $38,400 \mathrm{clumps} / \mathrm{rai}$ & $12.13^{\mathrm{c}} \pm 3.560$ & $20.70^{\mathrm{c}} \pm 4.598$ & $141.00^{\mathrm{a}} \pm 5.780$ \\
\hline 4. $48,000 \mathrm{clumps} / \mathrm{rai}$ & $10.80^{\mathrm{cd}} \pm 3.368$ & $18.55^{\mathrm{d}} \pm 3.714$ & $140.63^{\mathrm{a}} \pm 7.361$ \\
\hline 5. $56,320 \mathrm{clumps} / \mathrm{rai}$ & $10.03^{\mathrm{d}} \pm 2.475$ & $17.18^{\mathrm{d}} \pm 3.273$ & $137.32^{\mathrm{b}} \pm 7.781$ \\
\hline $\mathrm{CV} \%$ & 30.99 & 28.24 & 5.12 \\
\hline Significant & $*$ & $*$ & $*$ \\
\hline
\end{tabular}

The number of heads per clump gradually changed from 13.50 to 7.40 heads/clump as the densities increased (Table 2). The number of heads per clump was affected by high density and was significantly greater in the 22,400 clumps/rai than in higher densities. There were no significant differences in number of heads per clump between the 30,720 and 38,400 clumps/rai and also between 48,000 and 56,320 clumps/rai. The difference in the head numbers per clump was such that the density had to be low enough to provide a significant difference. Variation in head number is generally reflected in tiller number [5]. However, it was reported that head number and tiller number of 5 rice cultivars in Iran increased with increasing density [4].

There was no significant difference in the number of filled grains per head in all treatments (Table 2). Moreover, there was no significant difference in the number of unfilled grains per head in all treatments. Filled grains per head varied from 118.11 to 98.12 grains/head in $22,400,30,720,38,400$, 48,000 and 56,320 clumps/rai, respectively. Similarly, the unfilled grain followed the same pattern, varied from 17.28 to 13.11 grains/head in $22,400,30,720,38,400,48,000$ and 56,320 clumps/rai, respectively. It was showed that rice plants have the ability to translocate stored assimilates to fill grains in different plant densities.

Table 2 Number of head/clump and number of filled grain and unfilled grain/head.

\begin{tabular}{cccc}
\hline \multirow{2}{*}{ Treatment } & \multirow{2}{*}{ Heads/clump } & \multicolumn{2}{c}{ Number/head } \\
\cline { 3 - 4 } & & $118.11 \pm 8.433$ & Unfilled grain \\
\hline 1. 22,400 clumps/rai & $13.50^{\mathrm{a}} \pm 2.606$ & $110.58 \pm 11.807$ & $17.280 \pm 4.046$ \\
$2.30,720$ clumps/rai & $10.95^{\mathrm{b}} \pm 2.605$ & $108.23 \pm 10.200$ & $16.717 \pm 6.507$ \\
$3.38,400$ clumps/rai & $10.00^{\mathrm{b}} \pm 2.271$ & $103.76 \pm 22.551$ & $15.307 \pm 4.591$ \\
$4.48,000$ clumps/rai & $8.10^{\mathrm{c}} \pm 1.586$ & $98.12 \pm 9.129$ & $13.112 \pm 1.213$ \\
$5.56,320$ clumps/rai & $7.40^{\mathrm{c}} \pm 1.429$ & 12.80 & 26.84 \\
\hline CV\% & 30.33 & $\mathrm{~ns}$ & $\mathrm{~ns}$ \\
\hline Significant & $*$ & &
\end{tabular}

Seed moisture content was the lowest in the 48,000 clumps/rai density and the greatest in the 56,320 clumps/rai (Table 3). There were significant differences in seed moisture contents between the 48,000 density and those of 22,400, 30,720 and 56,320 densities. Seed moisture contents varied from 11.50 to $11.87 \%$

It was found that grain yield was the greatest when planting at 22,400 clumps/rai with $786.38 \mathrm{~kg} / \mathrm{rai}$ (Table 3). Rice planted at 30,720, 38,400, 48,000 and 56,320 clumps/rai produced 671.74, 664.94, 618.07 and $590.06 \mathrm{~kg} / \mathrm{rai}$, respectively. There was a significant difference in grain yield between those planted at $22,400,30,720,38,400$ and those planted at 48,000 and 56,320 clumps/rai. Grain yield increased by about $168.31 \mathrm{~kg} / \mathrm{rai}$ by decreasing plant density from 48,000 to 22,400 clumps/rai. Thai farmers can not only 
http://wjst.wu.ac.th

lower their seedling cost by half but also gain a higher grain yield. The lower density produced more tillers per clump, and may be due to more solar radiation. The higher grain yield in treatment 1 as compared to treatment 5 might contribute to higher plant tiller in treatment 1 that provided more root to supply nutrients. Unfortunately, the weight of 100 seeds was not recorded to confirm the higher yield in treatment 1 . Moreover, rice planted by the use of the parachuting method may provide more effective weed control that might contribute to the high grain yield [6]. The grain yield in higher density was affected by plant density. Increasing plant densities associated with conventional practices decreased crop performance [7].

Table 3 Seed moisture content and grain yield/rai.

\begin{tabular}{ccc}
\hline Treatment & Seed moisture content (\%) & Grain yield (kg/rai) \\
\hline $1.22,400$ clumps/rai & $11.69^{\mathrm{b}} \pm 0.305$ & $786.38^{\mathrm{a}} \pm 178.854$ \\
$2.30,720$ clumps/rai & $11.78^{\mathrm{bc}} \pm 0.248$ & $671.74^{\mathrm{ab}} \pm 118.036$ \\
$3.38,400$ clumps/rai & $11.65^{\mathrm{ab}} \pm 0.190$ & $664.94^{\mathrm{ab}} \pm 105.927$ \\
$4.48,000 \mathrm{clumps} /$ rai & $11.50^{\mathrm{a}} \pm 0.223$ & $618.07^{\mathrm{b}} \pm 74.195$ \\
$5.56,320 \mathrm{clumps} / \mathrm{rai}$ & $11.87^{\mathrm{c}} \pm 0.261$ & $590.06^{\mathrm{b}} \pm 50.738$ \\
\hline CV\% & 2.33 & 18.41 \\
\hline Significant & $*$ & $*$ \\
\hline
\end{tabular}

\section{Conclusions}

It is clearly shown that the most suitable plant density of rice using the parachute planting method was 22,400 clumps/rai with a grain yield of $786.38 \mathrm{~kg} / \mathrm{rai}$. The higher yield in low density planting could be obtained from higher tillers per clump, higher head numbers and higher seed weight per clump. Parachute planting with a suitable plant density would reduce seedling cost by as much as a half. Moreover, farmers gained benefit from a high grain yield and effective weed control.

\section{Acknowledgements}

The authors are grateful to the Faculty of Science and Industrial Technology, Prince of Songkla University Surat Thani campus for financial support and The Pathum Thani Rice Research Center.

\section{References}

[1] Office of Agriculture, Surat Thani province. Seed rates for rice sowing. (Unpublished Paper) Office of Agriculture, Surat Thani province, 2011.

[2] HR Bozorgi, A Faraji and RK Danesh. Effect of plant density on yield and yield components of rice. World Appl. Sci. J. 2011; 12, 2053-7.

[3] C Sampetch. Field Crop Production Physiology (in Thai). Department of Field Crops, Faculty of Agriculture, Kasetsart University, Thailand, 1999.

[4] HR Mobasser, R Yadi, M Azizi, AM Ghanbari and M Samdaliri. Effect of density on morphological characteristics related-lodging on yield and yield components in varieties rice (Oryza sativa L.) in Iran. Am. Euras. J. Agr. Environ. Sci. 2009; 5, 745-54.

[5] S Fukai, C Searl, H Baiquni, S Choengthong and M Kywe. Growth and grain: Yield of contrasting barley cultivars under different plant densities. Field Crops Res. 1990; 23, 239-54.

[6] S Intalang, N Chuensuk and W Intalang. Rice Weed Control and Weed Control in Rice Grown using Parachute Method (Unpublished Paper). Pathum Thani Rice Research Center, Pathum Thani, Thailand, 2005.

[7] XQ Lin, DF Zhu, HZ Chen, SH Cheng and N Uphoff. Effect of plant density and nitrogen fertilizer rates on grain yield and nitrogen uptake of hybrid rice (Oryza sativa L.). J. Agr. Biotech. Sustain. Dev. 2009; 1, 044-053. 